\title{
GENETIC TRANSFORMATION OF Eucalyptus camaldulensis BY AGROBALISTIC METHOD ${ }^{1}$
}

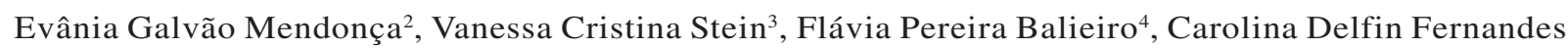
Lima $^{3}$, Breno Régis Santos ${ }^{4}$ e Luciano Vilela Paiva ${ }^{5}$

\begin{abstract}
Eucalyptus stands in the setting of worldwide forestry due to its adaptability, rapid growth, production of high-quality and low cost of wood pulp fibers. The eucalyptus convetional breeding is impaired mainlly by the long life cycle making the genetic transformation systems an important tool for this purpose. However, this system requires in vitro eficient protocols for plant induction, regeneration and seletion, that allow to obtain transgenic plants from the transformed cell groups. The aim of this work was to evaluate the callus formation and to optimize the leaves and callus genetic transformation protocol by using the Agrobacterium tumefaciens system. Concerning callus formation, two different culture media were evaluated: MS medium supplemented with auxin, cytokinin (M1) and the MS medium with reduced nitrogen concentration and supplemented with auxin, cytokinin coconut water (M2). To establish the leave genetic transformation, those were exposed to agrobiolistics technique (gene gun), to tissue injury, and A. tumesfasciens EHA 105 contening the vetor pCambia 3301 (35S::GUS::NOS), for gene transference and to establish the callus transformation thoses were exposed only to A. tumefasciens. For both experiments, the influence of different infection periods was evaluated. The M2 medium provided the best values for callus sizea and fresh and dry weight. The leaves genetic transformation using the agrobiolistics technique was effective, the gus gene transient expression could be observed. No significant differences were obtained in the infection periods ( 4,6 and 8 minutes). The callus genetic transformation with A. tumefaciens also promotend the gus gene transient expression on the callus co-cultiveted for $15 \mathrm{e}$ 30 minutes. The transformed callus was transfered to a regeneration and selection medium and transformed plants were obtained.
\end{abstract}

Keyword: A. tumefasciens EHA 105; pCambia 3301; Tissue culture; Transient expression.

\section{TRANSFORMAÇÃO GENÉTICA DE Eucalyptus camaldulensis VIA AGROBIOBALISTICA}

\begin{abstract}
RESUMO-O Eucalyptus destaca-se no cenário silvicultural mundial devido à sua adaptabilidade, crescimento rápido e produção de fibra de baixo custo e com alta qualidade. O melhoramento convencional do gênero é dificultado, principlamente, pelo seu longo ciclo de vida, tornando a transformação genética importante ferramenta para esse propósito. Esse processo requer o desenvolvimento de protocolo eficiente de progagação in vitro para indução, regeneração e seleção que permita a obtenção de plantas transgênicas a partir de grupos de células transformadas. Os objetivos deste trabalho foram avalair a formação de calos e otimizar o protocolo de transformação genética de folhas e calos através da infecção por A. tumefaciens. Para a formação de calos foram avaliados dois meios de cultura: meio de cultura MS supplementado com auxina e citocinina (M1) e meio de cultura MS com concentração de nitrogênio reduzida e suplementado com auxinas, citocininas e água de coco (M2). Para estabelecer o protocolo de transformação genética de E. camaldulensis,
\end{abstract}

\footnotetext{
${ }^{1}$ Recebido em 08.07.2012 aceito para publicação em 12.05.2013.

${ }^{2}$ Programa de Pós-Graduação em Universidade Federal de Lavras, Laboratório Central de Biologia Molecular. E-mail: <evaniafloresta@yahoo.com.br>e<f.balieiro@hotmail.com>.

${ }^{3}$ Universidade Federal de Lavras, EMBRAPA, Brasil. Universidade Federal de Goiás, Universidade Federal de Goias - Campus Jatobá.E-mail: <vanessa.stein@hotmail.com>e < carolima_bio@hotmail.com>.

${ }^{4}$ Universidade Federal de Alfenas, UNIFAL/MG, Brasil. E-mail: <brenors@ yahoo.com.br>.

${ }^{5}$ Universidade Federal de Lavras, Departamento de Química<luciano@ dqui.ufla.br>
} 
as folhas foram expostas à técnica de agrobiobalística, utilizando-se o bombardeador com micropartículas para realizar ferimentos nos tecidos; e A. tumefasciens EHA 105 contendo o vetor pCambia 3301 (35S::GUS::NOS) para a transferência do gene, enquanto para a transformação genética dos calos estes foram somente infectados com A. tumefasciens. Em ambos os experimentos foi avaliada a influência de diferentes períodos de infecção. $O$ meio de cultura $M 2$ promoveu os melhores valores de volume, massa seca e massa fresca. A transformação genética de folhas através da técnica de agrobiobalística foi efetiva, sendo possível observar a expressão transiente do gene gus, mas não houve diferenças significativas entre os períodos de infecção (4, 6 e 8 min). Os calos infectados por 15 e 30 min com A. tumefasciens também apresentaram expressão transiente do gene gus quando foram tranferidos para meio de cultura de regeneração e seleção e apresentaram formação de brotos.

Palavras-chave: A. tumefasciens EHA 105; pCambia 3301; Expressão transiente.

\section{INTRODUCTION}

Eucalyptus species are responsible for the large world reforestation areas due to the genus species number, the ecological plasticity and the industrial raw material. Brazilian industries use the eucalyptus as raw material mainly for production of pulp, paper and other derivatives, representing 5\% of Gross Domestic Product (GDP), generating 16 billion in exports and approximately 2 million jobs (SBS, 2011).

The silvicultural practices and conventional breeding have contributed significantly to increasing productivity in forest plantations, generating high economic value species. But, the conventional methods have limitations mainlly due to the long reproductive cycle of the species and to the difficulty in achieving significant improvements in complex traits, such as wood properties and tolerance to abiotic and biotic stresses (Nehra et al., 2005).

Therefore, in vitro culture systems and genetic engineering offer opportunities to produce new genotypes through processes, such as mutagenesis, somaclonal variation and genetic transformation (Confalonieri et al., 2003). According to Matsunaga et al. (2012), genetic engineering is a powerful tool for effective wood plants breeding, but no genetically modified Eucalyptus has been commercially used yet. It has been observed that the selected genotypes transformation, such as E. camaldulensis (Mullins et al. 1997), is only available when clonal explants are used, but because of the low transformation and regeneration capacity, the introduction of useful genes into practical important woody species has been delayed in comparison with other plants (Matsuga, et al., 2012).
To improve this, it is necessary to know the species behavior under in vitro conditions first (Stein et al., 2010). In this sense, the Eucalyptus species as Eucalyptus gunnii (Hervé et al., 2001), E. grandis $x$ E. urophylla (Alves et al., 2004), E. camaldulensis (Rahim et al., 2003, Dibax et al., 2005), E. erythronema and E. stricklandii (Glocke et al., 2006), E. globulus (Borges et al., 2011) have been widely studied and the indirect organogenesis is one of the techniques used for micropropagation, providing a high rate of callus shoots regeneration (Lainé and David, 1994; Moralejo et al., 1998). The main advantage of using indirect organogenesis as a tool for clonal plants mass production and regeneration is their high multiplication rates, reproducing uniform plants on large scale (Arenhart and Zaffari, 2008). But, the in vitro organogenesis process is a complex process, involving multiple activities of external and internal factors, as interaction among explant source, culture medium and environment (Joy IV and Thorpe, 1999).

Therewith, the in vitro micropropagation and the genetic transformation have attracted attention. The genetic transformation uses the foolowing two strategies for gene transfer in plants: direct and indirect system. The aim of the direct transference is the biolistic method (gene gun) and the indirect transference is the aim of Agrobacterium method. In the latter method, a a vector (eg. Agrobacterium tumefaciens) is used to promote the gene transfer. A variation of biolistic technique is the agrobiolistic method, using the biolistic method combined with Agrobacterium. This variation has the advantage of increasing the frequency of transformants, since the tissue injury does not affect the plant cell and it is sufficient for T-DNA transfer induction (Bidney et al., 1992; Brasileiro et al., 1996). 
Thus, efficient methods for selected clonal regeneration through indirect organogenic, using leaf explant or callus may constitute an alternative to vegetative propagation, as well as to attend genetic transformation. The objective of this study was to evaluate the effects of coconut water and nitrogen reduction in the induction of organogenic callus of E. camaldulensis, to develop genetic transformation, regeneration and selection system.

\section{MATERIALAND METHODS}

\subsection{Effect of coconut water and nitrogen reduction in the formation of $E$. camaldulensis callus.}

Leaf segments $\left(1 \mathrm{~cm}^{2}\right)$ from E.camaldulensis seedlings established in vitro were used for callus induction. Such segments were inoculated, with the abaxial side in contact with the MS medium (Murashige and Skoog, 1962), supplemented with $4.4 \mathrm{mM}$ of BAP, 2.7 mM of NAA, $3 \%$ sucrose, $6 \%$ agar (M1) or in contact with the modified MS medium containing salts with half of the original concentration and supplemented with $4.4 \mathrm{mM}$ of BAP, NAA $2.7 \mathrm{mM}, 10 \%$ coconut water (coconut $\mathrm{Kero}^{\circledR}$ ), $3 \%$ sucrose and $0.6 \%$ agar (M2). The culture media had the $\mathrm{pH}$ adjusted to 5.8 before autoclaving at $1 \mathrm{~atm}$ at $121^{\circ} \mathrm{C}$ for 20 minutes.

The explants were manteined in a growth chamber under dark and at a temperature of $27^{\circ} \pm 2$. The experimental design was completely randomized with five replicates of ten plants each. The variables were the following: size, fresh and dry weight and percentage of leaf area covered by callus (score), reaching the following grades: $0=0 \%, 1=25 \%, 2=50 \%, 3=75 \%$ and $4=100 \%$ of leaf area covered by callus. The fresh and dry weight variables were analyzed by Tukey test and the score was analyzed using the Mann-Whitney test 5\% (Ferreira, 2011).

\subsection{Genetic transformation.}

\subsubsection{Agrobiolistics transformation of Eucalyptus camaldulensis leave}

The biolistic method was used to have macro and micro injury leave tissues and to increase the Agrobacterium transformation efficiency. Thus, the biolistics were performed by particle accelerator protocol described by Sanford et al. (1991) and the M10 (GTE Sylvania Chemicals/Metals) tungsten microparticles (null microparticle) were prepared based on the protocol described by Aragão et al., (1996). For the leave explants bombardeament, the helium pressure was 1200 PSI and microparticle flight distance was $9.5 \mathrm{~cm}$. Each leaf explants recived one shot.

After that, the bombarded (with null microparticle) leaf explants were put in contact with A. tumefaciens. For this, the A. tumefaciens EHA 105, containing the vector pCambia 3301 (35S :: GUS :: NOS) was grown overnight in LB liquid medium containing kanamycin (50 mg. $\mathrm{L}^{-1}$ ) until reaching 0.95 optical density (OD). Then, the explants were put in contact with the bacteria culture for 0, 4, 6 or 8 minutes under agitation. Afterwards, they dried on sterile paper towel and inoculated into Petri dish containing M2 culture medium, where they were co-cultiveted on growth chamber under dark and at a temperature of $27^{\circ} \pm 2$ for 5 days. The experimental design was a completely randomized one with five replications containing 10 plants each.

The efficiency of the protocol was assessed by expression of the gus gene thorugh a reaction catalyzed by $\beta$-glucuronidase in the presence of X-gluc (Jefferson, 1987). For histochemical analysis, ten explants were taken from each treatment at random and immersed in solution composed of $10 \mathrm{mM} \mathrm{Na}{ }_{2}$ EDTA. $\mathrm{H}_{2} \mathrm{O}, 0.1 \%$ Triton X-100, $0.1 \mathrm{mM} \mathrm{NaH}_{2} \mathrm{PO} 4,0.5 \mathrm{mM} \mathrm{K}_{4} \mathrm{Fe}(\mathrm{CN})_{6}$, and $250 \mathrm{mg} \cdot \mathrm{mL}^{-1}$ of $\mathrm{X}$-gluc, incubated at $37^{\circ} \mathrm{C}$ for approximately 16 hours. After the reaction period, the explants were transferred to an ethanol solution. The gus expression evaluation was performed with the Olympus SZH10 stereoscope with a Canon Power Shot A620 camera attached to it. The blue dots were counted and the images were recorded digitally.

The experiment analysis was conducted by ScottKnott test at 5\% (Ferreira, 2011).

\subsubsection{Agrobacterium transformation of Eucalyptus camaldulensis callus}

For the callus induction, the leaf explants $\left(1 \mathrm{~cm}^{2}\right)$ of E.camaldulensis seedlings established in vitro, were inoculated in test tubes containing M2 culture medium and placed in a growth chamber under dark and at a temperature of $27^{\circ} \pm 2$ until the formation of callus (30 days). The cultivation of A. tumefaciens EHA 105 containing the pCambia 3301 vector (35S :: GUS :: NOS) and the processing methodology were performed using a protocol developed by Cruz et al. (2004).

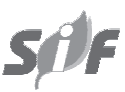

Revista Árvore, Viçosa-MG, v.37, n.3, p.419-429, 2013 
After obtaining a bacterial culture with 0.2 OD, the calli were infected with A. tumefaciens solution for 0,15 and 30 minutes. After infection, the calli were dried on sterile paper towel and placed in Petri dish containing culture medium for regeneration (M3) with half salts original concentration of MS medium (MS/2) and supplemented with $2.64 \mathrm{mM}$ BAP, $0.5 \mathrm{mM}$ ANA, $10 \%$ coconut water (coconut $\operatorname{Kero}^{\circledR}$ ), $3 \%$ sucrose and $0.6 \%$ agar. The co-culture was mantained in a growth chamber under dark, at a temperature of $27^{\circ} \pm 2$ for 5 days. After the co-cultive, one repetition was used to verify gene gus transient expression (Jefferson, 1987).

The remaining replicates were transferred to regeneration M3 medium supplemented with antibiotic Timentin $®\left(500 \mathrm{mg} . \mathrm{L}^{-1}\right)$ for 15 days. The regenerated shoots $(0.5 \mathrm{~cm})$ were transferred to a fresh MS medium supplemented with antibiotic Timentin $®\left(500 \mathrm{mg} . \mathrm{L}^{-1}\right)$ and herbicide Finale ${ }^{\circledR}\left(0.006 \mathrm{mg} \cdot \mathrm{mL}^{-1}=6 \mathrm{PPT}\right)$ and manteined for 15 days. After 15 days, the explants were transferred to a fresch MS medium suplemented with Timentin ${ }^{\circledR}\left(500 \mathrm{mg} . \mathrm{L}^{-1}\right)$ and herbicide Finale ${ }^{\circledR}$ $\left(0.009 \mathrm{mg} \cdot \mathrm{mL}^{-1}=9 \mathrm{PPT}\right)$, where they remained until the assessment time (30 days).

The experiments were conducted in a growth chamber in a 16-hour photoperiod with irradiance of $40 \mathrm{~mol} \mathrm{~m} \mathrm{~m}^{-2} \mathrm{~s}^{-1}$, at a temperature of $27^{\circ} \pm 2^{\circ} \mathrm{C}$. The experimental design was completely randomized with five replicates of 8 explants each. The parameters evaluated were the number of shoots/callus and the number of survived explants.

\section{RESULTS}

\subsection{Effect of the nitrogen and coconut water on the formation of Eucalyptus camaldulensis callus}

The callus initiation in the leaf explants were observed after 20 days of inoculation in M1culture medium suplemented with cytokinins and auxin, as weel as in the M2 culture medium, suplemented with cytokinins, auxin, coconut water and reduced nitrogen concentration (M2).

The callus formation in the leaf explants were evaluated at 30 days and transfered to the light condition. Considering the leaf area covered by callus were not observed, using the Mann-Whitney 5\% test, statistical different between the M1 and M2 medium. The score average of callus formation was 3, corresponding to an average of $75 \%$ of the leaf area covered by callus (Table 1 ).
However, the callus growth characteristics such as fresh weight, dry weight and callus size were afected by the culture medium formulation, showing statistical difference by the Tukey test at 5\% (Table 1). The calli cultivated on M1 medium were smaller $\left(2.22 \mathrm{~mm}^{3}\right)$ and had lower dry weight $(0.32 \mathrm{~g})$, compared to the size $\left(3.20 \mathrm{~mm}^{3}\right)$ and the dry weight $(0.49 \mathrm{~g})$ of the callus inoculated on M2 medium at 30 days, and this behavior were maintained until the final assessment (60 days). The dry weight of the callus found on the M2 medium $(0.49 \mathrm{~g})$, was $35 \%$ higher than on the M1 medium $(0.32 \mathrm{~g})$, indicating that on M2 medium, the calli absorved more carbon and nutrients.

The nitrogen reduction and the addition of coconut water into the culture medium (M2) were important to improve the callus growth, and to provide water, carbon and nutrient absorption. The callus development were bulkier, which are best suited to a subculture, because it has higher fresh and dry weight.

\subsection{Agrobiolistics transformation of Eucalyptus camaldulensis leave}

To establish the genetic transformation of E. camaldulensis leaf explants by the agrobiolistics technique, the influence of different infection periods with A. tumesfasciens EHA 105 containing the $p$ Cambia 3301 vetor (35S::GUS::NOS) was tested. The leaf tissue exposed to biobalistic technique and subsequentelly to infection periods of 4,6 and 8 minuts showed blue spots with transient expression of $\beta$-glucuronidase enzyme (Figure 1).

The agrobiolistics technique transformation efficiency, based on the transient expression of âglucuronidase (Figure 2), did not show significant differences (Skott-Knott test at 5\%) among times of infection; however, the explants infected for 8 minutes showed the highest number of blue spots (45) while the explants infected for 4 minutes showed only 32 spots. It is important to consider that this is a transient expression and that this expression can decrease until the gene becomes stable.

\subsection{Agrobacterium transformation of Eucalyptus camaldulensis callus}

To establish the genetic transformation of callus of E. camaldulensis by the Agrobacterium transformation, calli at 30 days of age were used, formed on the M2 medium (Figure 3A). Most of the calli, co- 
Table 1 - Mean values of the score, fresh mass weight, dry mass weight and size of E. camaldulensis callus.

Tabela 1 - Valores médios das características score, massa fresca, massa seca e volume de calos de E. camaldulensis, em função da calogênese.

\begin{tabular}{ccccc}
\hline Treatment & Callus formation (score) & Fresh weight $(\mathrm{g})$ & Dry weight $(\mathrm{g})$ & Size $^{\left(\mathrm{mm}^{3}\right)}$ \\
\hline M1 & $3.40 \mathrm{a}$ & $1.56 \mathrm{a}$ & $0.32 \mathrm{a}$ & $2.22 \mathrm{a}$ \\
M2 & $3.18 \mathrm{a}$ & $2.50 \mathrm{~b}$ & $0.49 \mathrm{~b}$ & $3.20 \mathrm{~b}$ \\
\hline
\end{tabular}

* Means followed by different letters in the column are statistically different by Mann-Whitney test (score) and Tukey test ( $p>0.05)$. *Médias seguidas de letras diferentes na coluna diferem estatisticamente entre si, pelo teste de Mann-Whitney (score) e Tukey ( $\mathrm{p}>0,05$ ).
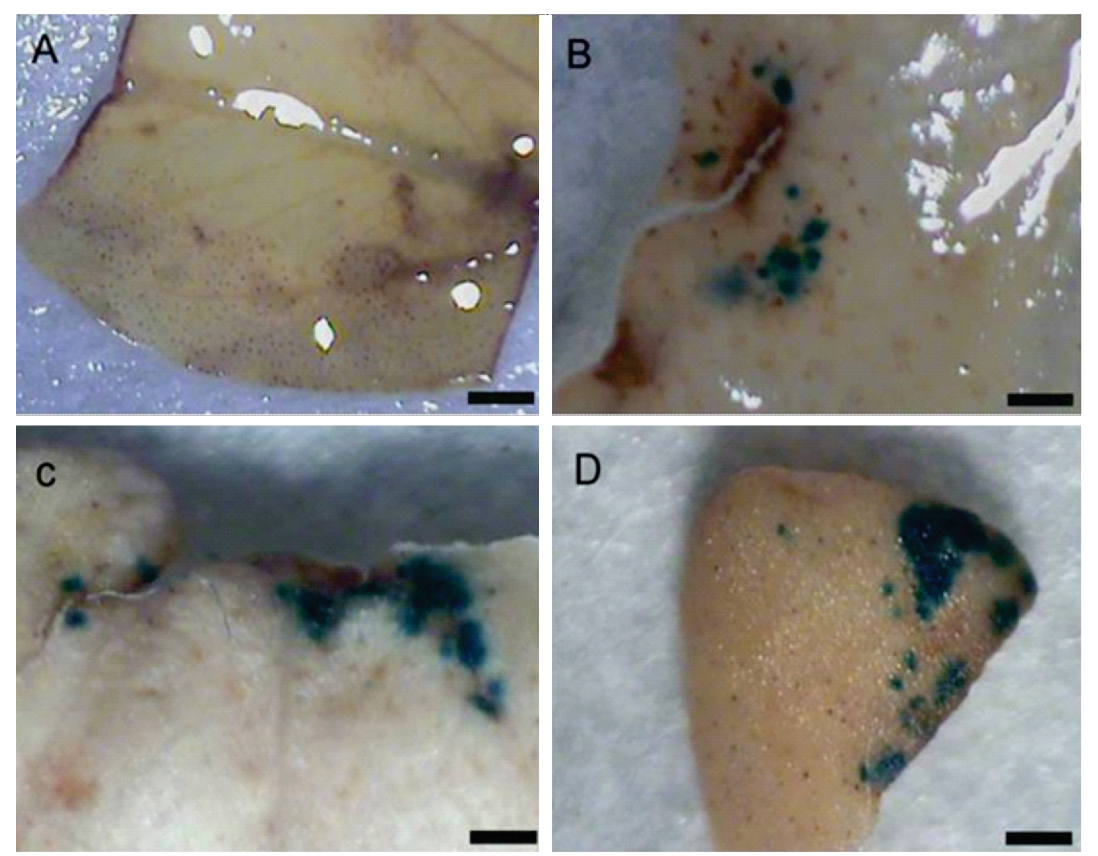

Figure 1 - Transient expression of gus gene in E. camaldulensis leaves after co-culture in $\mathrm{OD}_{600 \mathrm{~nm}}=0.95$. (A) Control leaf, (B) Leaf showing gus gene expression - 4-minute inoculation, (C) Leaf showing gus gene expression 6-minute inoculation, and (D) leaf showing gus gene expression-8-minute inoculation (Bar $1 \mathrm{~mm}$ ).

Figure 1 - Expressão transiente do gene gus em folhas de $\boldsymbol{E}$. camaldulensis, após cocultura em $O D_{600 \mathrm{~mm}}=0,95$. (A) Folha não inoculada; (B) Folha exibindo expressão do gene gus - inoculação por 4 min; $(C)$ Folha exibindo expressão do gene gus - inoculação por 6 min; e (D) Folha exibindo expressão do gene gus - inoculação por 8 min (Barra $1 \mathrm{~mm}$ ).

cultiveted with A. tumesfasciens EHA 105 containing the $p$ Cambia 3301 vetor (35S::GUS::NOS), showed the transient expression of the gus reporter gene. On the figure 3, it is possible to see the control callus, without spots (Figure 5B), the callus infected for 5 minutes (Figure 5C) and for 30 minutes (Figure 5D) with darker spots, corresponding to the gus transient expression.

The transformed calli were transfered to a regeneration medium (M3) and after 30 days, a shoot formation was found. The average of callus shoot formation was 4.5 shoots/calli, regardelles of the infection time.

The shoots, with aproximatelly $0.5 \mathrm{~cm}$, were transfered to a fresh regeneration culture medium (M3), containing herbicide Finale ${ }^{\circledR} 6$ PPT, where the remained for 15 days (Table 2) to select the regenereted transformed shoots. However, during this period, no shoot death was found, including the control plants. Thus, the shoots were transferred to a fresh medium, with increased concentration of the herbicide 9PPT. After 15 days, 


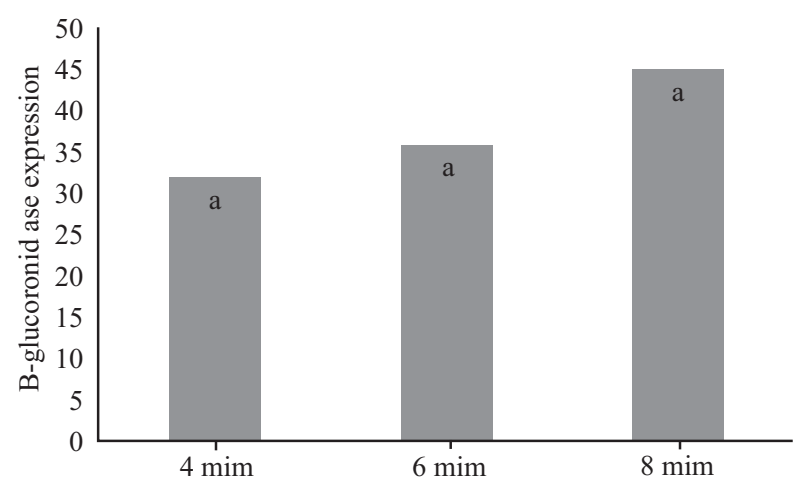

Figure 2-Evaluation of infection time. Leaf explants submitted to different infection times, bombarded with a pressure of 1200 PSI at a distance of $9.5 \mathrm{~cm}$ from the target. Evaluations conducted 5 days after inoculation. Means with the same letter do not differ significantly at $5 \%$, by the Scott-Knott test.

Figura 2 - Avaliação de tempo de infecção. Explantes foliares submetidos a diferentes tempos de infecção, bombardeados com uma pressão de disparo de 1200 PSI a uma distância de 9,5 cm do alvo. Avaliações realizadas cinco dias após a inoculação. Médias com a mesma letra não diferem significativamente entre si, pelo teste de Scott-Knott a 5\%. it was found that $60.5 \%$ and $66.6 \%$ of the plants, infected for 15 minutes or 30 minutes, respectivelly, survived to the 9PPT selection medium.

\section{DISCUSSION}

\subsection{Efect of nitrogen and coconut water on Eucalyptus camaldulensis callus induction}

The coconut water and the reduced concentration of concentration are important to increase the growth of E. camaldulensis callus. Acording to Hall et al. (2000), for many species, the coconut water contains substances that are essential for the callus growth and regeneration. According to Taiz and Zeiger (2004), the coconut water contains cytokinins and other nutritional factors that stimulate the division of mature cells. In addiction, according to Ferreira et al. (1998), the coconut water contains glucose, fructose, minerals, myo-inositol, nucletides and other organic compounds which are necessary for induction and development of the callus. These factors can explain the stimulatory effect of coconut water as observed on callus inoculated on M2 medium.
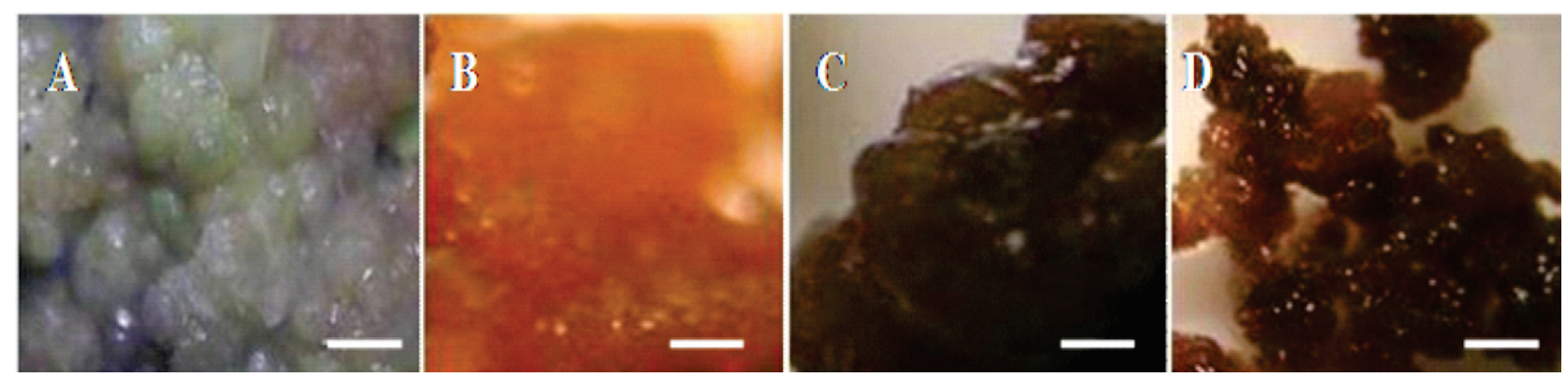

Figure 3 - E. camaldulensis calli. (A) The mass of calli formed after 30 days in culture medium. (B) Negative control. (C) Callus infected for 15 minutes. (D) Callus infected for 30 minutes. (B, C and D) Callus submitted to reaction of the enzyme â-glucuronidase in the presence of the X-gluc substrate (bar $1 \mathrm{~mm}$ ).

Figura 3 - Calos de E. camaldulensis. (A) Massa de calos formada após 30 dias em meio de cultura. (B) Controle negativo. (C) Calos infectados por $15 \mathrm{~min}$. (D) Calos infectados por $30 \mathrm{~min}(B, C$ e D) submetidos à reação da enzima â-glucoronidase, na presença do substrato de X-gluc (barra $1 \mathrm{~mm}$ ).

Table 2 - Number of infected calli, number of shoots/callus, number of shoots in selective medium (9PPT) and number of living shoots of E. camaldulensis at different times of infection with A. tumefaciens.

Tabela 2 - Número de calos infectados, número de brotos/calo, número de plântulas no meio seletivo (9PPT) e número de plântulas vivas de $\boldsymbol{E}$. camaldulensis, em diferentes tempos de infecção com A. tumefaciens.

\begin{tabular}{ccccc}
\hline Treatment & $N^{\circ}$ of infected callus & $N^{\circ}$ of shoots/calus & $N^{\circ}$ of plants $(9 P P T)$ & $N^{\circ}$ of surveived plants \\
\hline Infection $15 \mathrm{~min}$ & 40 & $4.57 \mathrm{a}$ & $38 \mathrm{a}$ & $23 \mathrm{a}$ \\
Infection $30 \mathrm{~min}$ & 40 & $4.50 \mathrm{a}$ & $36 \mathrm{a}$ & $24 \mathrm{a}$ \\
\hline
\end{tabular}

Revista Árvore, Viçosa-MG, v.37, n.3, p.419-429, 2013 
Dornelas and Vieira (1994) and Hall et al. (2000) reported the importance of coconut water on the development and elongation of shoots of Passiflora spp callus. Rani and Nair (2006), working with Vitex Negundo L. report that in the lack of coconut water, healthy callus are formed, but this callus did not show multiplication of the shoots, even being organogenic responsives. For Calanthe hybrids, the increase in the concentration of coconut water in the culture medium increases the shoot length, fresh and dry weight of shoot and root, leaf width, number of roots and leaf area (Baque et al., 2011). For Saccharum officinarum L., the highest callus induction percentage and the maximum weight were obtained from explants grown on the MS medium supplemented with $3 \mathrm{mg} / 1$ 2,4-D and $15 \%$ (v/v) coconut water (Khamrit et al., 2012). On the other hand, Pinto et. al. (2010), did not observed the same behavior for Passiflora alata.

Regarding the influence of the reduced concentration of nitrogen on the growth of E. camaldulensis callus, it is known that the in vitro growth and morphogenesis are significantly influenced by the nitrogen availability and its provided form $\left(\mathrm{NH}_{4}^{+}, \mathrm{NO}^{-}\right)$. The nitrogen is incorporated into amino acids and may also serve as a reprogramming signal for the metabolism of nitrogen, carbon and resource allocation (Wang et al., 2003).

It is assumed that most cells accumulated carbon in the starch form, which acts as a energy reserve required for morphogenesis, since it quickly disappears when the meristems or leaf primordia are formed. Therefore, the E. camaldulensis callus formation process, observed in M2 medium, is promoted by the the ammonium/nitrate ratio. According to Lee et al., (2011) the ammonium/ nitrate ratio controls the $\mathrm{pH}$ of the media, stimulates morphogenesis and embryogenesis, and thus it is important for inducing callus formation in many woody plant cultures. So, the form of nitrogen supply seems to be beneficial for cell wall formation and for the activity of growth regulators as well.

\subsection{Agrobiolistics transformation of Eucalyptus camaldulensis leave}

Considering that the nature of the biolistic delivery system has many potential variables, it is necessary to optimize the system for a more efficient delivery of plasmid DNA into the target tissues (Dhir et al., 2010). In addition, considering the Agrobacterium delivery system, it is also found that the tissue injury method prior to bacterial infection plays an important role in T-DNA delivery (Aggarwal et al., 2011). Thus, the biolistc thecnique was used as injury method combined with $A$. tumefaciens infection in this work.

The efficiency of biolistic depends on physical parameters such as the velocity, size and number of the particle. According to Dhir et al. (2010), the degree of tissue damage depends on the type of the explant, the particle density and the acceleration pressure. The pressure of the helium gas (1200 PSI) and the target distance $(9.5 \mathrm{~cm})$ used in this study were based on the information described by Sanford et al. (1993). The authors report that pressure of helium gas near 1000 PSI are considered optimal for most applications because the lower pressures do not cause sufficient acceleration for the microparticles penetrate cells and higher pressures cause irrecoverable damage in the tissue to be transformed. The authors also report that the shorter distances cause higher accelerations, which may damage the tissue, compromising their regeneration, or even causing their death.

On the other hand, the transformation of calli of Eucalyptus from ITC-3, a superior clone, was tried by transforming pAHC 25 and $\mathrm{pHX} 4$ vectors carrying glucoronidase and hygromycin phosphotransferase, respectively. Particle bombardment was done using PDS1000/He particle delivery system. However, gus expression could not be achieved (Smitha and Vijayalakshmi, 2010).

Moreover, on this work, the biolistc thecnique was combined with $A$. tumefaciens infection. The $A$. tumesfasciens EHA 105 is a highly virulent species but the long contact with explants can damage the tissue, hindering the transformed plant regeneration. For E. tereticornis, two strains of A. tumefaciens (EHA105 and LBA4404) (harbouring pBI121 plasmid) were tested and the strain EHA105 was found to be more efficient (Aggarwal et al., 2011). Considering this, and that the infection period did not differ for the gene trasnference, it is suggested that 4 minutes of infection is the best treatment to promote an efficient transformation with less damage to the explant.

Reporter genes also have played an important role in developing and optimizing transformation protocols for plant species. The $\beta$-glucuronidase (GUS) is one of most useful reporter used for determining the number of transgene expressing cells per bombardment (Men 
et al., 2003). Thus, the agrobiolistic technique transformation was efficient for the gene $g u s$ transference. It could be found the transient expression of $\beta$ glucuronidase on leaf explants. But, it is important to consider that this is a transient expression and it can decrease until the gene becomes stable.

In the literature, there are many reports on the rates of transient expression conversion to stable expression. Finer and McMullen (1990) reported only $1 \%$ of conversion and Klein et al. (1998), 5\% of stable expression. However, Serrano et al. (1996), working with transformatoin of cotyledons of E. globules found that after two months on the culture, the transformed explants gus was similar to that observed in this study.

\subsection{Agrobacterium transformation of Eucalyptus camaldulensis callus}

The results found for the genetic transformation of callus of E. camaldulensis by A. tumefaciens showed that there is no effect of the times of infection for the variable number of buds and number of survived seedlings on the selective medium. On the other hand, according to Alcantara et al. (2011), the hybrid E. grandis $\times$ E. urophylla showed the highest rate $(100 \%)$ of explants expressing uidA gene with the 5 days on co-culture.

Concerning the regeneretion of $E$. camaldulensis callus transformed, the average was 4.5 shoots/calli formations, regardelles of the infection time. For $E$. globulus, the highest frequency of transgenic shoot regeneration from hypocotyls with shoot apex was $7.4 \%$ and the average frequency in four experiments was $4.0 \%$ (Matsunga et al., 2012).

For the selection of the transformed plants, the callus passed through two rounds of selections. According to Long et al. (2011), the discrimination between transgenic and non-transgenic calluses became even more evident after the second round of selection. Bombarded calluses selected on $5 \mathrm{mg} / \mathrm{L}$ PPT or $50 \mathrm{mg} / \mathrm{l}$ paromomycin grew vigorously during the first two to three rounds of selection. Selvaraj et al. (2010), seleceting transformed callus of Cucumis sativus L. cv. Poinsett76, observed that compared to kanamycin, no escapes were recorded in PPT selection. PPT had killed all the non-transformed shoot buds, allowing only transformed shoot buds to grow further from the explants.

\section{CONCLUSIONS}

The culture medium containing coconut water and reduced nitrogen concentration are the most suitable for callus formation on E. camaldulensis leaf explants.

The Agrobiolistics transformation can be used to transforme E. camaldulensis leaf explants and the infection period did not differ for the gene trasnference. Four minutes of infection is the best treatment to promote an efficient transformation with less damage to the explant.

The Agrobacterium method is efficient in transforming $E$. camaldulensis callus with $A$. tumesfasciens EHA 105 containing pCambia 3301 (35S::GUS::NOS) vector and it can regenerate and select the transgenic plants with PPT.

\section{ACKNOWLEDGEMENTS}

This research was partially supported by FAPEMIG and CAPES. We would like to thank Dra. Andréia Almeira Carneiro from Embrapa Milho and Sorgo for providing the plasmid.

\section{REFERENCES}

AGGARWAL, D.; KUMAR, A.; REDDY, M.S. Agrobacterium tumefaciens mediated genetic transformation of selected elite clone(s) of Eucalyptus tereticornis. Acta Physiologiae Plantarum,v.33, n.5,p.1603-1611, 2011.

ALCANTARA, G. B.; BESPALHOK FILHO, J. C.; QUOIRIN, M. Organogenesis and transient genetic transformation of the hybrid Eucalyptus grandis $\times$ Eucalyptus urophylla. Scientia Agricola,v.68, n.2, p.246-251, 2011.

ALVES, E. C. S.; XAVIER, A.; OTONI, W. C. Organogênese de explante foliar de clones de Eucalyptus grandis x E. urophylla. Pesquisa Agropecuária Brasileira, v.39, n.5, p.421430, 2004.

ARAGÃO, F. J. L. et al.Inheritance of foreing genes in transgenic bean (Phaseolus vulgaris L) co-transformed via particle bombardment.

Theoretical and Applied Genetics, v.93, n.1, p.142-150, 1996. 
ARENHART, R. A.; ZAFFARI, G.R. Otimização do protocolo de icropropagação por organogênese indireta de Eucalyptus grandis. Revista de Ciências Agroveterinárias, v.7, n.1, p.16-22, 2008.

BAQUE, M. A. et al. Effect of light quality, sucrose and coconut water concentration on the microporpagation ofCalanthe hybrids ('Bukduseong' $\times$ 'Hyesung' and 'Chunkwang' $\times$ 'Hyesung'). AJCS, v.5, n.10, p.1247-1254, 2011.

BIDNEY, D. et al. Microprojectile bombardment of plant-tissues increases transformation frequency by Agrobacterium-tumefaciens. Plant

Molecular Biology, v.18, n.2, p.301-313, 1992.

BORGES, S. R. et al.Multiplicação in vitro de clones híbridos de Eucalyptus globulus. Revista Árvore, v.35, n.2, p.173-182, 2011.

BRASILEIRO, A. C. M. et al.Susceptibility of common and tepary beans to Agrobacteriummediated transformation using microprojectile bombardment. Journal of the American Society for Horticultural Science, v.121, n.5, p.810-815, 1996.

CONFALONIERI, M. et al. In vitro culture and genetic engineering of Populus spp.: synergy for forestry tree improvement. Plant Cell, Tissue and Organ Culture, v.72, n.2, p.109-138, 2003.

CRUZ, A. R. R. et al.Metodologias para obtenção de plantas transformadas de Coffea canephora por co-cultivo de calos embriogênicos com Agrobacterium tumefaciens. Brasília: Embrapa Recursos Genéticos e Biotecnologia, 2004. 15p. (Boletim de Pesquisa e Desenvolvimento).

DHIR, S. et al. Optimization and transformation of Arundo donax L. using particle bombardment African Journal of Biotechnology, v.9, n.39, p.6460-6469, 2010.

DIBAX, R. et al.Plant regeneration from cotyledonary explants of Eucalyptus camaldulensis. Scientia Agricola, v.62, n.4, p.406-412, 2005.

DORNELAS, M. C.; VIEIRA, M. L. C. Tissue culture studies on species of Passiflora. Plant Cell, Tissue and Organ Culture, v.36, n.1, p.211-217, 1994.
FERREIRA, D. F. SISVAR: a computer statistical analysis system. Ciência e Agrotecnologia, v.35, n.6, p.1039-1042,2011.

FERREIRA, M. E.; CALDAS, L. S.; PEREIRA, E.A. Aplicações da cultura de tecidos no melhoramento genético de plantas. In: TORRES, A.C.; CALDAS, L.S.; BUSO, J.A. (Ed.). Cultura de tecidos e transformação genética de plantas. Brasília: Embrapa-SPI/EMBRAPACNPH, 1998. v. 1, p. 21-43.

FINER, J. J.; MCMULLEN, M.D. Transformation of cotton (Gossypium-hirsutum-L) via particle bombardment. Plant Cell Reports, v.8, n.10,p.586-589, 1990.

GLOCKE, P. et al. Micropropagation of juvenile tissue of Eucalyptus erythronema x Eucalyptus stricklandii cv. 'Urrbrae Gem'. In Vitro Celland Developmental Biology Plant, v.42, n.1, p.139-143, 2006.

HALL, R. M. et al. Efficient organogenesis of an Australian passionfruit hybrid (Passiflora edulis $\mathrm{x}$ Passiflora edulis var. flavicarpa) suitable for gene delivery. Australian Journalof Botany, v.48, n.5, p.673-680, 2000.

HERVÉ, P. et al. Procedure for shoot organogenesis in vitro from leaves and nodes of an elite Eucalyptus gunnii clone: comparative histology. Plant Science, v.161, n.4, p.645-653, 2001.

JEFFERSON, R. A. Assaying chimeric genes in plants: the GUS gene fusion system. Plant Molecular Biology, v.5, n.4, p.387-405, 1987.

JOY IV, R.W.; THORPE, T.A. Shoot morphogenesis: structure, phusiology, biotecmistry and biology. In: SOH, W.Y.; BHOJWANI, S.S. (Ed.). Morphogenesis in plant tissue cultures. London: Kluwer Academic, 1999. p.171-214.

KHAMRIT, R.; JAISIL, P.; BUNNAG, S. Callus induction, regeneration and transformation ofsugarcane (Saccharum officinarum L.) with chitinasegene using particle bombardment. African Journal of Biotechnology,v.11, n.24, p.6612-6618, 2012.

Revista Árvore, Viçosa-MG, v.37, n.3, p.419-429, 2013 
KLEIN, T. M. et al. Factors influencing gene delivery into Zea mays cells by high-velocity microprojectiles. Bio/Tecnology, v.6, n.1, p.559-563, 1998.

LAINÉ, E.; DAVID, A. Regeneration of plants from leaf explants of micropropagated clonal Eucalyptus grandis. Plant Cell Reports, v.13, p.473-476, 1994.

LEE, Y. et al.Influence of auxins, cytokinins, and nitrogen on productionof rutin from callus and adventitious roots of the white mulberrytree (Morus alba L.) Plant Cell, Tissue and Organ Culture, v.105, n.1, p.9-19, 2011.

LONG, D. et al. Comparison of three selectable marker genes for transformation of tall fescue (Festuca arundinacea Schreb.) plants by particle bombardment. In Vitro Cellular \& Developmental Biology,v.47, p.658666, 2011.

MATSUNAGA, E. et al.Agrobacterium-mediated transformation of Eucalyptus globulususing explants with shoot apex with introduction of bacterial choline oxidase gene to enhance salt tolerance. Plant Cell Reports,v. 31, p.225-235, 2012.

MEN, S. et al.Genetic transformationof two species of orchid by biolistic bombardment. Plant Cell Reports, v.21, p.592-598, 2003.

MORALEJO, M. et al. Generation of transgenic Eucalyptus globulus plantlets through Agrobacterium tumefaciens mediated transformation. Australian Journal of Plant Physiology, v.25, n.2, p.207-212, 1998.

MURASHIGE, T.; SKOOG, F. A revised médium for rapid growth and biossays with tobacco cultures. Physiologia Plantarum, v.15, p.473-407, 1962.

MULLINS, K.V. et al. Regeneration and transformation of Eucalyptus camaldulensis. Plant Cell Reports, v.16, n.11, p. 66-73, 1997.

Revista Árvore, Viçosa-MG, v.37, n.3, p.419-429, 2013
NEHRA, N. S. et al. Forest biotechnology: innovative methods, emerging opportunities. In Vitro Celland Developmental Biology - Plant, v.41, n.6, p.701-717, 2005.

PINTO, A.P.C. et al.In vitro organogenesis of Passiflora alata.In Vitro Cellular \& Developmental Biology - Plant, v.46, n.1, p.28-33, 2010.

RANI, D. N.; NAIR, G. M.Effects of plant growth regulators on high frequency shoot multiplication and callus regeneration of an important Indian medicinal plant, nirgundi (Vitex negundo L.) In Vitro Cellular \& Developmental Biology - Plant, v.42, n.1, p.66-73, 2006.

RAHIM, F.; JABEEN, M.; ILAHI, I. Mass propagation in Eucalyptus camaldulensis Dehn. Asian Journal of Plant Sciences, v.2, n.2, p.184-187, 2003.

SANFORD, J.C. et al.. An improved, helium-driven biolistic device. Tecnique, v.3, n.1, p.3-16, 1991.

SANFORD, J. C.; SMITH, F.D.; RUSSELL, J. A. Optimizing the biolistic process for different biological applications. Methods in Enzymology, v.217, n.1, p.483-509, 1993.

SELVARAJ, N. et al.Evaluation of green fluorescent protein as a reporter gene and phosphinothricin as the selective agent for achieving a higher recovery of transformants in cucumber (Cucumissativus L. cv. Poinsett76) via Agrobacterium tumefaciens. In Vitro Cellular \& Developmental Biology Plant,v.46, p.329-337, 2010.

SERRANO, L. et al.Genetic transformation of Eucalyptus globulus through biolistics: complementary development of procedures for organogenesis from zygotic embryos and stable transformation of corresponding proloferating tissue. Journal of Experimental Botany, v.47, n.295, p.285-290, 1996.

STEIN, V. C. et al. Ultrastructural calli analysis of Inga vera Willd. subsp. Affinis (DC.) T.D. Penn. Revista Árvore, v.34, n.5, p.789-796, 2010.

SMITHA, G.; VIJAYALAKSHMI, C. Genetic Transformation of ITC ITC 3, ptus tereticornisa Superior clone of Eucalyptus tereticornis.

Indian Journal of Agricultural Research, v.44, n.3, p.229-232, 2010. 
SOCIEDADE BRASILEIRA DE SILVICULTURA - SBS. Fatos e números do Brasil Florestal. 2011. Disponível em: <http://www.sbs.org.br/Fatos e Numeros do Brasil Florestal.pdf>. Acesso em: 10 maio 2011.

TAIZ, L.; ZEIGER, E. Fisiologia vegetal. Porto Alegre: Artmed, 2004. 719p.
WANG, L. Z.; FANG, L.; HIPEL, K. W.

Cooperative water resources allocation based on equitable water rights.In:IEEE INTERNATIONAL CONFERENCE ON SYSTEMS, Man and

Cybernetics, Hyatt Regency. Washington, DC: 2003. Proceedings... Washington, DC:2003. p.4425-4430. 
